are on the editorial board, and this first number augurs well for the future. Everyone interested in psychiatry must welcome such a valuable addition as this to the literature.

\section{Technical Education Abstracts}

Technical Education Abstracts was first publishod earlier this year, and, in view of the domand, production has had to be converted rapidly from litho to letterpress. 'The curront issuo is a double number covering the period January-March 1961 (1, Nos. 2 and 3. Pp. xxii +58-109. (London: National Foundation for Educational Rosearch in England and Wales, 79 Wimpole Street, 1961.) Subseription rate: 42s. per volumo of four quarterly issues). It is published quarterly by the Information Service of the National Foundation for Educational Research in England and Walos, and the abstracts are arranged according to a classification adaptod from the Universal Decimal Classification. Besides periodieals in the usual sense, articles in the daily Press are covered as well as questions in Hansard, certain roports of conforonces, papers and books dealing with technical education, such as The Complete Scientist. For the subseription of $£ 22 s$, running from January 1 to Decembor 31, subseribers, on this issue, should receivo a comprehensive guide to tho published literature on the subject, well arrangod, with essential bibliographical data and subject and author and title indexes.

\section{World Directory of Dental Schools}

THe World Health Organization has produced another valuable work of reference (World Directory of Dental Schools. Pp. 228. Geneva: World Health Organization; London: H.M. Stationery Offico, 1961. 15 Swiss franes; 25s.; 5 dollars). Tho most up-todate information from Government departments and dental schools of seventy countries has been compiled to give a comprohensive volume on systems of dental oducation and training institutions. For each country, the number of dental schools and the dentist/population ratios are given, followed by details of administration, conditions of admission, curricula, examinations, and regulations governing licence to practise. Finally, in table form, each dental school is listed with its namo and address, its size, year of foundation and annual tuition fees.

\section{Imperial College of Science and Technology}

THe fifty-fourth annual report of the Governing Body of the Imperial College of Science and Technology covers the year 1960-61 (Pp. iv +129 . London: Imperial College of Science and Technology, 1961). During this period the number of full-time studonts rose to 2,682 , compared with 2,656 in $1959-60$, of whom 1,669 were undergraduates. The report includes, besides the Rector's report and the usual appendixes listing publications, benefactions, special lectures, and statistics of staff and students, Sir Cyril Hinshelwood's Commemoration Day address. There were 553 part-time students and the number of postgraduate research students increased, while that of postgraduato students taking advanced courses was fairly steady. Science degrees accounted. for 43 per cent of the 180 higher and 475 first degrees awarded, and the 387 students awarded the D.T.C. included 282 technologists. Two-thirds of the students are still in lodgings and only just over 10 per cent are in halls of residence; 23 per cent of the students were from overseas, with nearly 2 from the Commonwealth to each foreign student; 31 per cent come from within 30 miles of the College and 46 per cent from other parts of the United Kingdom. A marginal increase in academic staff brought the total to 419 , including 42 professors and 73 roadors. Grants for research totalled $£ 355,000$, of which $£ 200,000$ came from the Department of Scientific and Industrial Research and $£ 50,600$ from the Atomic Energy Authority.

\section{Calendar of AGARD Meetings}

THE Advisory Group for Aoronautical Research and Dovelopment (AGARD) of the North Atlantic Treaty Organization will be holding the following tochnical meetings during 1962: "Tho High Temperature Aspects of Hypersonic Fluid Dynamics" (Rhodo-Saint-Genòse, Bolgium, April 3-6); "Fifth AGARD Combustion and Propulsion Colloquium" (Brunswick, April 9-13); "Improving Documentation Committoe Activities in the NATO Countrios" (London, April 22-27); "V/STOL Handling Characteristics" (Paris, April); "Manual on Aircraft I Loads" (Paris, July 3-6); Structures and Materials Panel Meeting (Paris, July 9-11); "Clinical Aviation Medicine and Aero Space Medicine". (Paris, July 9-15); round table discussions of Fluid Dynamics Panel on previously selected topics (Paris, July 9-11); "Sound, Light and Heat Sensing" (Paris, July 9-11); Flight Mechanics Panel Meeting (Paris, July 9-11); twelfth AGARD general assembly and seminar on "The Manned Aircraft Weapon SystemPast, Present and Future" (Paris, July 12-13); "V/STOL Propulsion" (London, September); "Propagation of Low Frequencies and Radio Froquency Noise below 300 Kilocycles" (Munich, October); Structures and Materials Panel Moeting (Paris, October) ; "Magneto-Fluid-Dynamics Seminar" (Paris, October 15-19); "Nuclear Rocket Propulsion" (Brussels, Autumn); "Take-off and Landing Symposium" (Autumn); Flight Mechanics Panel meeting (Autumn); "Cardiovascular Problems" (Paris, Autumn). Further information can be obtained from Advisory Group for Aeronautical Research and Development, North Atlantic Treaty Organization, 64 ruo do Varenne, Paris VII.

\section{Harwell Course on the Instrumentation of Reactors}

Trre first Harwell reactor school course on the instrumentation of reactors will be hold at Durley Hall, Bournemouth, during February 12-23, 1962. 'Ihis course is designed to replace the control and instrumentation of reactors course, which on tho six occasions it was held was attended by moro than 250 students from Britain and oversoas, excluding staff from the Atomic Energy Authority. The syllabus will include: elementary reactor physics; quantitios to be measured and basic methods of measurement; noutron and radiation detectors; pulso and d.c.measuremont channels; health physics instrumentation; neutron flux scanning; principles and design of control mechanisms; design principles of reactor safety circuits, relays and other logic devices; temperature and flow measurements; burst slug detection; data processing in large reactors; installation aspects and commissioning of reactor instrumentation. The fee for the course will be 50 guineas, exclusive of accommodation. Details and application forms are availablo from the Manager, Reactor School, Atomic Finorgy Research Establishment, Harwoll, Didcot, Berks. 